\title{
Effect of Sickle Cell Crises Prevention Guide for Children on Parents Knowledge and Reported Practices
}

\author{
Hanaa, I. Elsayed ${ }^{1} \quad$ Fatma, A. Abd Elrazek ${ }^{1} \quad$ Seham, M. Ragab ${ }^{2}$ \\ 1. Lecturer of Pediatric Nursing, Faculty of Nursing, Menoufia University, Egypt \\ 2.Professor of Pediatrics, Faculty of Medicine, Menoufia University, Egypt
}

\begin{abstract}
Sickle cell anemia (SCA) is a global health concern associated with high childhood morbidity and mortality. The major associated complication is sickle cell crisis which cause frequent hospital admission. Therefore, the purpose of this study was to examine the effect of sickle cell crises prevention guide for children on parents' knowledge and reported practices. The study was conducted at Hematology \& oncology unit of Pediatric department at Menoufia University Hospital and Health insurance hospital for children. A quazi experimental design was used. A convenient sample of parents with sickle cell children in the above mentioned settings were selected (34 parents) from January to November 2018. One tool was used for data collection consists of 4sections questionnaire to assess parents' knowledge and practice. The results of this study revealed that there were knowledge deficit between parents' about sickle cell disease, approximately two thirds of parents $(64.7 \%)$ had improved on post intervention for reported practices of crisis prevention than pre intervention. Also, $79.4 \%$ of parents didn't use social and cultural practices in prevention of sickle cell crises post intervention. Therefore, there was a highly statistical significance differences between pre and post intervention. Conclusion, implementing sickle cell prevention guide improve parents' knowledge and reported practices for prevention of crises to promote children recovery. Recommendation, ensure that sickle cell booklets are made available to hospitals for parents in order to remind themselves on treatment and prevention of sickle cell crises.
\end{abstract}

Keywords: Sickle cell crisis, knowledge, Practice

DOI: $10.7176 / \mathrm{JHMN} / 64-07$

Publication date:July $31^{\text {st }} 2019$

\section{I-Introduction}

Sickle cell anemia (SCA) is an autosomal recessive, gene hemoglobinopathy caused by abnormal red blood cells that arises from abnormal amino acid in the $\beta$-globin chain which causes red blood cells to lose their characteristic of biconcave disc shape (Bartolucci \& Galacteros, 2012). It is a common life-threatening haematological disorder that affects millions of children worldwide which leads to a shortened life expectancy (Awd, 2018; Abbas, 2014). It includes a variety of pathological conditions caused by inheritance of sickle hemoglobin either in a homozygous state or in a heterozygous state (Aken'ova, 2013).

Sickle cell disease is one of the major chronic diseases that pose a significant psychosocial burden on children and their parents (Amoran et al., 2017). The highest prevalence of sickle-cell disease $70 \%$ in subSaharan Africa. It has been estimated that in the developing world SCD led to annual loss of several millions of disability-adjusted life each year's (El Safy, 2016). Africa is the most affected continent with 200,000 new born affected by sickle cell anemia per year (WHO, 2006 \& Diallo, 2002). In many Arab countries, consanguinity may reach $25 \%-30 \%$ of all marriages, a frequency which contributes to the increased rates of inherited genetic disorders (Tadmouri et al., 2009: Modell \& Darlison, 2008). The increasing number of SCA will continue to have a major impact particularly on healthcare services and financing (Piel et al., 2013).

Sickle cell anemia is essentially a multisystem disorder that has effects on all body organ. Abnormal sickleshaped erythrocytes disrupt blood flow in small blood vessels, it causes vaso-occlusion and inflammation which lead to distal tissue ischemia and acute painful sickle-cell crisis (Lal \&Vinchinsky, 2011). Repeated sickling and lead to parenchymal injury and chronic organ damage (Adewoyin et al., 2015). Also, sickling of red blood cells lead to splenic sequestration and a plastic anemia (Sparkenbaugh, 2013\& Rees, 2010). Crises may causes by precipitating trigger factor such as dehydration, a sudden change in body temperature, infection or environmental factors and hypoxia caused by stress or exercise ( Rees et al., 2003)

Vaso-occlusion crisis are primarily mechanisms that caused clinical manifestations of SCD (Howard \& Oteng-Ntim, 2012). The most common physical manifestations are painful vaso-occlusive episodes, dehydration, and delayed growth and sexual maturation (Purnima \& Jayant, 2018). Acute painful crisis is characterized by a sudden onset of pain that affect any part of the body, including the back, long bones and chest; the pain ranges from mild to severe or even excruciating and has been described as deep, gnawing, and throbbing. Pain episodes or crises can last for hours or days, and individuals with SCD may have episodes once or many times a year (Jenerette \& Leak, 2012: Rees et al., 2010).

The associated complications were infection, acute chest syndrome, renal dysfunction, retinopathy, avascular necrosis, and cholelithiasis (Ballas, 2018 and Howard \& Oteng-Ntim, 2012). Long-term and severe 
complications can include pneumococcal infections, organ failure and cerebral vascular accidents (Piel et al., 2013). Also SCD leads to poor quality of the life and increased mortality and morbidity in children and young adults as well as a primary reason for health care utilization and hospitalizations (Purnima \& Jayant, 2018 and Lattimer et al., 2010).

The treatment strategies to prevent crisis based on long-term transfusion therapy, hydration, hydroxyurea therapy, and pain management which result in multiple challenges and demands to parents of children with SCD, as those parents are often the primary caregivers (Poulami et al., 2017 : Abu Ali and Abdel Razeq, 2017 \& Yawn et al., 2014). Appropriate prevention practices will lead to reduction in the frequency of vaso-occlusive crisis, pain, anemia and splenic sequestration (Akinyanju \& Otaigbe, 2005). Timely intervention and appropriate prevention practices is essential for prevention complications of vaso-occlusive crisis through administration of plenty of fluid, avoid exposure to infection and too hot weather, avoid poorly ventilated area, schedule for vaccination, restrict vigorous exercise and give appropriate nutrition (Amoran et al., 2017\& Oni et al, 2012).

Children with SCD need optimal family support and care, especially in terms of prevent occurrence of crisis and providing adequate nutrition to achieve an optimum and steady state of health. Such favorable family environment and appropriate prevention measures has been shown to be a good prognostic index (Aliyu, Kato \& Taylor, 2008). The psychosocial burden and stress parents of sickle cell patients undergo could influence their attitude towards the care of their children (Amoran et al., 2017).

Nursing care is essential for pain management of children with SCD, it includes health education and prevention of subsequent sickle cell crisis (Valente et al., 2010). As well as, educating the family and SCD children about signs of infection and lifestyle behaviours that limited aggravate the disease (Joshua, Vichincky \& DeBaun, 2014; Xandra et al., 2008). Paediatric nurses have significant roles to medication administration, monitor the children signs of infection and dehydration, transcutaneous nerve stimulation and preserve function by physical therapy, (Van den et al., 2008). The failure to manage symptoms effectively can cause dysfunction within the family and an increasing burden of care and despair (Michael et al., 2008). Nurses are important conduits in the content and context of information as a primary care provider, thus influencing the quality of care and patient outcomes (Haywood et al., 2011).

\subsection{The purpose of the study :}

- To examine the effect of sickle cell crises prevention guide for children on parents knowledge and reported practices.

\subsection{Research hypothesis:}

- Parents of sickle cell disease children will be exhibit improvement in their knowledge and reported practices after receiving sickle cell crises prevention guide.

\subsection{Operational definitions:}

- Sickle cell crisis: it is a painful episode caused by abnormal sickle-shaped erythrocytes that occlude blood flow in micro vascular beds and leads to distal tissue ischemia.

- Knowledge: it is facts, information and skills acquired through experience or education of theoretical or practical understanding of subject.

- Practice: it is repeated performance or systematic exercise for the purpose of acquiring skills or proficiency

\section{Methods}

\subsection{Design:}

A quazi experimental design was used.

\subsection{Settings:}

This study was conducted at Hematology \& oncology unit of pediatric department at Menoufia University Hospital and Health insurance Hospital for children at Menoufia governorate.

\subsection{Sampling:}

A Convenience sample of 34 parents of sickle cell children was included in the study from the above mention settings.

\subsubsection{Inclusion Criteria:}

- Parents of children diagnosed with sickle cell disease.

\subsubsection{Exclusion Criteria:}

- Parents of children with sickle cell disease associated with other type of anemia. 


\subsection{Tool of data collection:}

2.4.1. One tool was used for data collection: It was adopted from Amoran et al., (2017) and modified by the researcher after reviewing related literature and based on guideline for sickle cell disease. This tool was divided into 4 parts:

- Part one: Social characteristics of studied sample. It contained questions such as age, level of education, number of children with sickle cell disease, educational level and previous training.

- Part two: Knowledge of Parents about sickle cell disease. It was aimed to assess parent's knowledge about sickle cell disease. It contained questions about definition, predisposing factors and sources of information about sickle cell disease.

- Part three: Practices of Parents with sickle cell children. This section was designed to assess practices towards prevention of sickle cell crises such as causes of crisis and methods of prevention.

- Part four: Social and cultural practices of parents on prevention of sickle cell crisis. This section was aimed to assess social and culture practices toward prevention of sickle cell crisis. It contained questions such as care and type of practice used.

\subsection{Tool development:}

It was adopted from Amoran et al., (2017) and modified by the researchers for data collection after a review of past and current literature related to sickle cell crisis prevention in children using, articles, periodicals, books and magazines to get acquainted with the various aspects of the research problem.

2.5.1. Validity: Before starting the data collection, the tool was translated into Arabic and tested for their content validity by a group of three professor experts in pediatric nursing.

2.5.2. Reliability of the tool: - Reliability test was done by using test-retest and Cronbach's alpha coefficients .The questionnaire was applied on them and retested after 2 weeks. The degree of coefficient test was 0.82 . It can be concluded that the tool has a high level of reliability

2.6.Pilot study A pilot study was carried out on 3 parent "10\%" of the sample in order to test the and clarity and applicability of tool included questionnaire as well as to estimate the average time needed to fill questionnaire. Those who shared in the pilot study were excluded from the main study sample

2.7. Approval: A certified consent acquired from the administrators to get permission for data collection after clarifying the aim of the study and intervention which could contribute to prevention of sickle cell crisis.

2.8. Ethical considerations: at the initial interview the researchers introduced themselves to the parents and sickle cell children and explained the aim of the study. Each participant was notified about the right to refuse or participate in the study with anonymity, and confidentiality of the information gathered was ensured. Finally, parent's formal consent for participations has been obtained and reassured that they had the right to withdraw from the study with no penalty.

\subsection{Procedure for data collection:}

Fieldwork: Data collection was conducted from January to November 2018.

\subsubsection{Assessment phase.}

The researchers introduce themselves to the parents and explained the purpose of the study, Parents were assessed individually at the beginning of the study for their social characteristics, knowledge about sickle cell disease, reported practices regarding sickle cell disease and crisis prevention measure (pre-intervention).

\subsubsection{Implementation phase.}

The sickle cell crisis prevention guide (Oni et al., 2012) was implemented to parents of children with sickle cell disease. Parents were divided into groups (each group interviewed one times per week). Every interview lasted for 30 to 45 minutes. Each (1 to 2) parents are considered as a group. So, each group took 2 educational sessions. First session include Intervention was carried out in focused on sickle cell disease:

- What is sickle cell disease?

- Types of sickle cell disease

- The effects of sickle cell disease

- Complication of sickle cell disease

- Treatment of sickle cell disease

Second session focus on knowledge for crisis prevention

- What are types of sickle cell crisis?

- What are predisposing factor of sickle cell crisis?

- Treatment of sickle cell crises 
- $\quad$ Practical Methods of preventing sickle cell crises at home

- Social and Cultural Practices of Parents with Sickle Cell Children

2.9.3. Evaluation phase: It was carried out after completing the sessions (1month) to determine the knowledge, reported practices of parents with sickle cell children in the direction of the prevention of sickle cell crises(postintervention).

2.10. Data processing and analysis: Data were analyzed using the IBM Statistical Package of Social Science (SPSS) version 20. Quantitative data were presented by mean (X) and standard deviation (SD). Qualitative data were presented in the form of frequency distribution tables, number and percentage. It was analysed by chisquare $(\chi 2)$ test.

\section{Results:}

Table 1: Social characteristics of studied sample

\begin{tabular}{|c|c|c|}
\hline Variables & $\mathrm{No}=34$ & $\%$ \\
\hline $\begin{array}{l}\text { Children age } \\
\mathrm{X} \pm \mathrm{SD}\end{array}$ & \multicolumn{2}{|c|}{$6.5882 \pm .68$} \\
\hline $\begin{array}{l}\text { Parents age } \\
X \pm S D\end{array}$ & \multicolumn{2}{|c|}{$30.20 \pm 4.78$} \\
\hline $\begin{array}{l}\text { Number of children in the family } \\
1-3 \\
4-6\end{array}$ & $\begin{array}{l}24 \\
10\end{array}$ & $\begin{array}{l}70.6 \\
29.4\end{array}$ \\
\hline $\begin{array}{l}\text { Children have sickle cell disease } \\
1 \text { child } \\
2 \text { children } \\
3 \text { or more }\end{array}$ & $\begin{array}{l}22 \\
6 \\
6 \\
\end{array}$ & $\begin{array}{l}64.7 \\
17.00 \\
17.00 \\
\end{array}$ \\
\hline $\begin{array}{l}\text { Parent Level of education } \\
\text { Primary } \\
\text { Secondary } \\
\text { Bachelor }\end{array}$ & $\begin{array}{l}4 \\
28 \\
2\end{array}$ & $\begin{array}{l}11.8 \\
84.4 \\
5.9\end{array}$ \\
\hline
\end{tabular}

Table 1 showed characteristics of studied parents and sickle cell children. These findings revealed that the mean age and standard deviation of children were $6.5882 \pm .68$. While, the mean age of parents were $30.20 \pm 4.78$. Also, 84, $4 \%$ of studied parents had secondary school. More than two thirds of family's (64.6) had only child had sickle disease in the family.

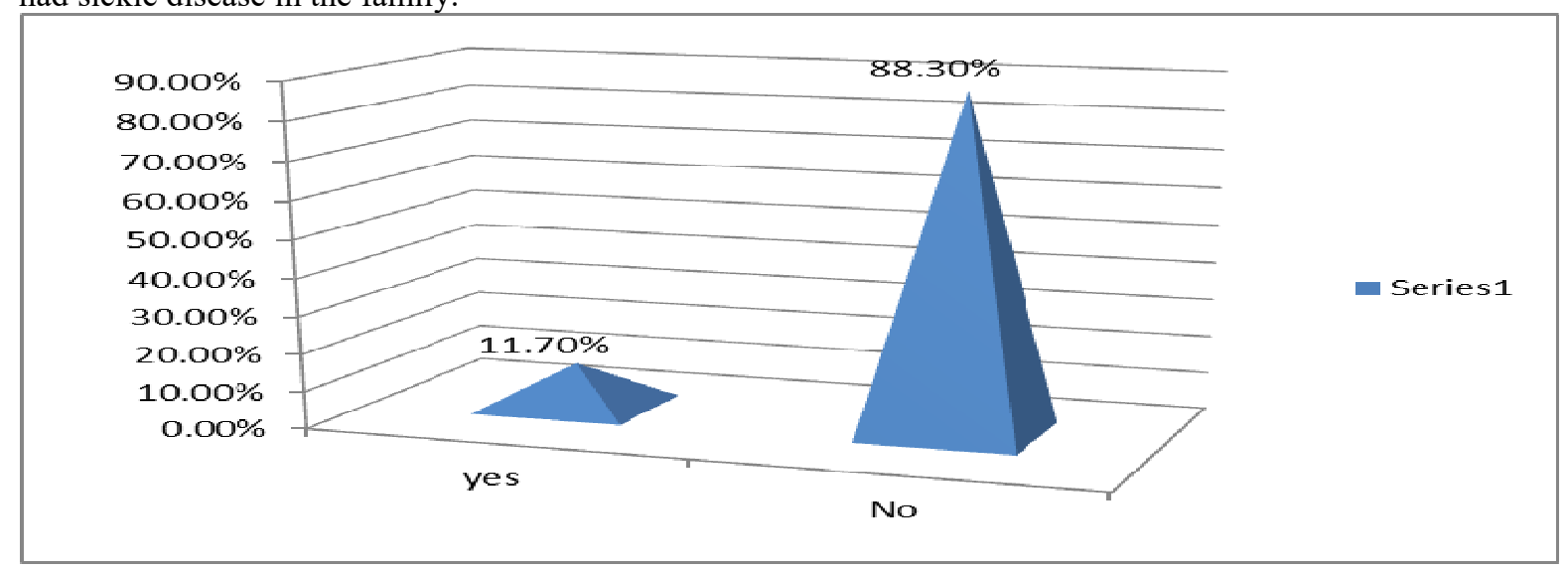

Figure (1): Previous training in Sickle Cell Disease.

Figure 1 illustrated previous training in sickle cell disease. The figure showed that $88.30 \%$ of parents had no previous training about sickle cell disease 
Table 2: Knowledge of Parents about sickle cell disease Pre and Post intervention

\begin{tabular}{|c|c|c|c|c|c|c|}
\hline \multirow[t]{2}{*}{$\overline{\text { Items }}$} & \multicolumn{2}{|c|}{$\begin{array}{r}\text { Pre - } \\
\text { intervention }\end{array}$} & \multicolumn{2}{|c|}{$\begin{array}{r}\text { Post } \\
\text { intervention }\end{array}$} & \multirow[t]{2}{*}{$\chi^{2}$} & \multirow[t]{2}{*}{$\begin{array}{r}\text { P- } \\
\text { value }\end{array}$} \\
\hline & $\begin{array}{l}\text { No } \\
34 \\
\end{array}$ & $\%$ & $\begin{array}{l}\text { No } \\
34 \\
\end{array}$ & $\%$ & & \\
\hline \begin{tabular}{l}
\multicolumn{2}{|c|}{ Define sickle cell disease } \\
a) Correct \\
b) Incorrect \\
\end{tabular} & $\begin{array}{l}0.0 \\
34 \\
\end{array}$ & $\begin{array}{l}100 \\
100\end{array}$ & $\begin{array}{l}32 \\
2 \\
\end{array}$ & $\begin{array}{l}94.1 \\
5.9\end{array}$ & 61.3 & $0.001 * *$ \\
\hline $\begin{array}{l}\text { What are the Predisposing factors for sickle cell crisis } \\
\text { a) Infection } \\
\text { b) Exposure to cold \& Fever } \\
\text { c) Doing activities } \\
\text { d) Dehydration } \\
\text { e) Don't know }\end{array}$ & $\begin{array}{l}0 \\
20 \\
4 \\
0 \\
10 \\
\end{array}$ & $\begin{array}{l}0.0 \\
58.8 \\
11.8 \\
0.0 \\
29.4 \\
\end{array}$ & $\begin{array}{l}12 \\
0 \\
0 \\
22 \\
0 \\
\end{array}$ & $\begin{array}{l}35.5 \\
0.0 \\
0.0 \\
64.7 \\
0.0 \\
\end{array}$ & 94.62 & $0.001 * *$ \\
\hline $\begin{array}{l}\text { Are sickle cell crises preventable } \\
\text { a) Yes } \\
\text { b) No }\end{array}$ & $\begin{array}{l}16 \\
18\end{array}$ & $\begin{array}{l}52.9 \\
47.1 \\
\end{array}$ & $\begin{array}{l}29 \\
5\end{array}$ & $\begin{array}{l}85.3 \\
14.7\end{array}$ & & $.004 * *$ \\
\hline $\begin{array}{l}\text { What are the Method of treating sickle cell crisis } \\
\text { a) Give plenty of fluid \& highly nutrient food } \\
\text { b) Keep child warm } \\
\text { c) Give prophylactic drugs } \\
\text { d) All of the above } \\
\text { e) Don't know }\end{array}$ & $\begin{array}{l}2 \\
6 \\
8 \\
0 \\
18 \\
\end{array}$ & $\begin{array}{l}5.9 \\
17.6 \\
23.5 \\
0.0 \\
52.9 \\
\end{array}$ & $\begin{array}{l}8 \\
0 \\
4 \\
22 \\
0 \\
\end{array}$ & $\begin{array}{l}23.5 \\
0.0 \\
11.8 \\
64.7 \\
0 \\
\end{array}$ & 68.98 & $.001 * *$ \\
\hline $\begin{array}{l}\text { What are the Source of information about sickle cell } \\
\text { crises prevention } \\
\text { a) Hospital staff } \\
\text { b) Internet } \\
\text { c) Family and friends } \\
\text { d) Others specify }\end{array}$ & $\begin{array}{l}24 \\
2 \\
4 \\
4\end{array}$ & $\begin{array}{l}70.6 \\
2.9 \\
5.9 \\
5.9 \\
\end{array}$ & $\begin{array}{l}34 \\
0 \\
0 \\
0\end{array}$ & $\begin{array}{l}100 \\
0.00 \\
0.00 \\
0.00\end{array}$ & 15.59 & $.001 * *$ \\
\hline Total & 34 & 100 & 34 & 100 & & \\
\hline
\end{tabular}

NB: ${ }^{* *} P<001$

ns means not significant

${ }^{*} P<05$

Table 2 showed Knowledge of Parents about sickle cell disease Pre and Post intervention. It was illustrated that none of parent identified definition of sickle cell disease pre intervention compared to $94.3 \%$ of them had correct answer on post intervention. As revealed from the table, parents had improve knowledge post intervention about predisposing factor of sickle cell crisis Also, there were highly statistical significant differences between pre and post intervention at $1 \%$ level of statistical significance.

Table (3): Reported Practices of Parents for Prevention of Sickle Cell Crises on Pre and Post intervention

\begin{tabular}{|c|c|c|c|c|c|c|c|}
\hline \multirow{2}{*}{\multicolumn{2}{|c|}{ Items }} & \multicolumn{2}{|c|}{ Pre - intervention } & \multicolumn{2}{|c|}{ Post intervention } & \multirow{2}{*}{$\chi^{2}$} & \multirow[t]{2}{*}{$\mathrm{P}$-value } \\
\hline & & No 34 & $\%$ & $\begin{array}{r}\text { No } \\
34 \\
\end{array}$ & $\%$ & & \\
\hline \multicolumn{2}{|c|}{$\begin{array}{l}\text { 1-Do you prevent sickle cell } \\
\text { crises before the child goes into a } \\
\text { crisis } \\
\begin{array}{l}\text { a) Yes } \\
\text { b) No }\end{array}\end{array}$} & $\begin{array}{l}12 \\
22\end{array}$ & $\begin{array}{l}35.3 \\
64.7\end{array}$ & $\begin{array}{l}34 \\
0\end{array}$ & $\begin{array}{l}100 \\
0.0\end{array}$ & & $0.00 * *$ \\
\hline $\begin{array}{l}\text { 2-Met } \\
\text { cell cr } \\
\text { a) } \\
\text { b) } \\
\text { c) } \\
\text { d) } \\
\text { e) }\end{array}$ & $\begin{array}{l}\text { ods of preventing sickle } \\
\text { ses } \\
\text { Give child plenty of fluids } \\
\text { Dress the child warm } \\
\text { clothes } \\
\text { Reduce activity } \\
\text { More oxygen } \\
\text { Don't know }\end{array}$ & $\begin{array}{l}2 \\
6 \\
4 \\
0 \\
22\end{array}$ & $\begin{array}{l}5.9 \\
17.6 \\
11.8 \\
0.0 \\
64.7\end{array}$ & $\begin{array}{l}24 \\
0 \\
0 \\
10 \\
0\end{array}$ & $\begin{array}{l}70.6 \\
0.0 \\
0.0 \\
29.4 \\
0.0\end{array}$ & 80.16 & $0.001 * *$ \\
\hline \multicolumn{2}{|l|}{ Total } & 34 & 100 & 34 & 100 & & \\
\hline
\end{tabular}


Table 3 showed reported practices of parents for prevention of sickle cell crises on pre and post intervention. It was revealed that more than one third of studied sample were identified methods of prevention sickle cell crisis pre intervention (35.3\%) compared to post intervention (100\%). As revealed from the table parents were provided plenty of fluids to reduce frequency of hospitalization $(70.6 \%)$ compared to $5.9 \%$ pre intervention. Therefore, there was a highly statistical significance differences between pre and post intervention.

Table (4): Social and Cultural Practices of Parents with Sickle Cell Children on Pre and Post intervention

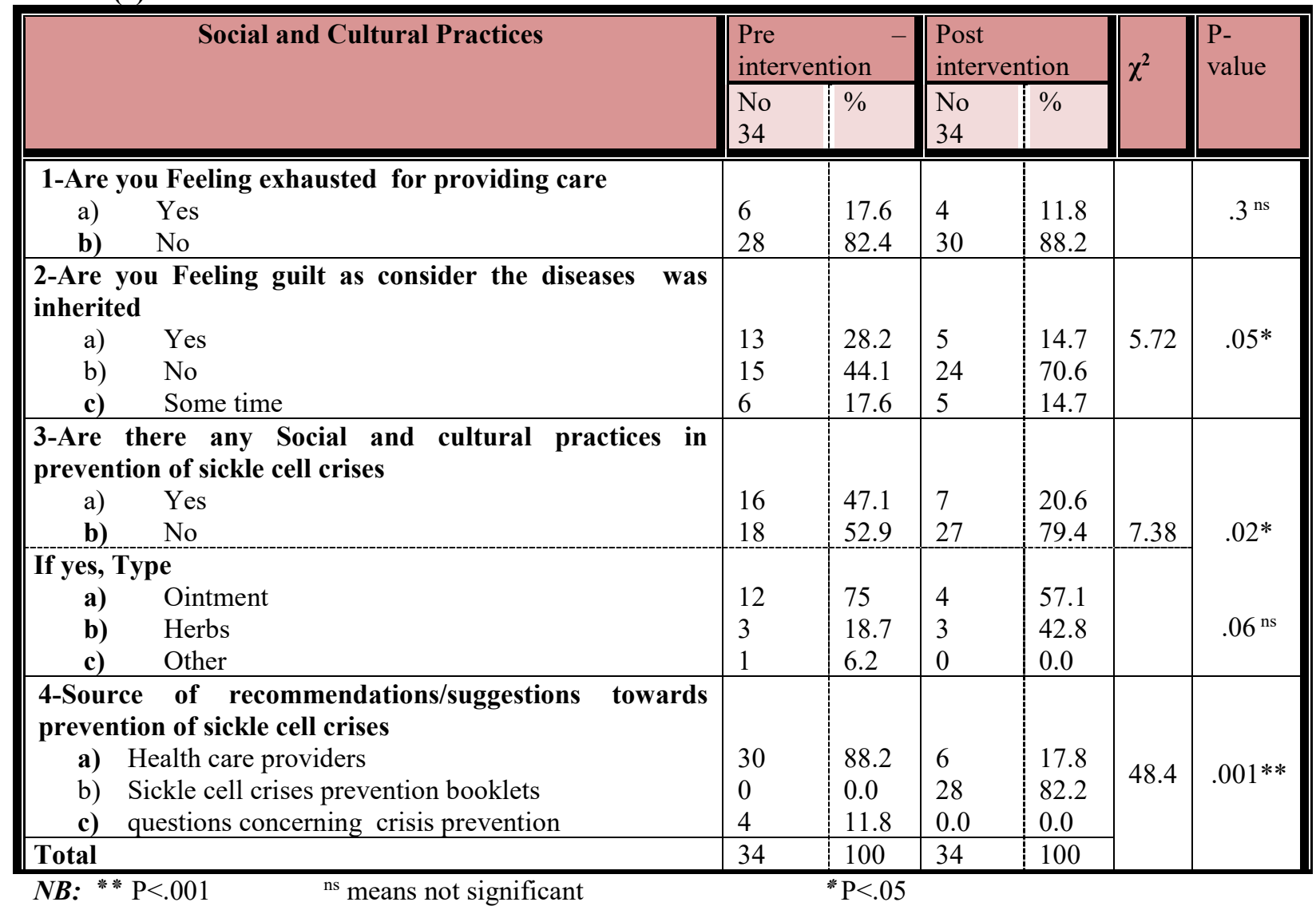

Table 4 represented Social and Cultural Practices of Parents with sickle cell Children on Pre and Post intervention. It was illustrated that majority of parents don't feel exhausted for providing care pre and post intervention (82.4\% and $88.2 \%$ respectively). Also, it was revealed that $52.9 \%$ of parents didn't use social and cultural practices in prevention of sickle cell crises on pre intervention compared to $79.4 \%$ on post intervention. Therefore, there were highly statistical significant differences between practices of nurses at $1 \%$ level of statistical significance.

\section{Discussion:}

Sickle cell disease is associated with high childhood morbidity and mortality as well as psychosocial, emotional burden and economic burden on the affected families. The current study hypothesized that Parents of sickle cell disease children will be exhibit improvement in their knowledge and reported practices after receiving sickle cell crises prevention guide. The results of the current study support the study hypotheses. The characteristics of studied sample revealed that the mean age and standard deviation of children were $6.5882 \pm .68$. While, the mean age and standard deviation of parents was $30.20 \pm 4.78$. This will allow parents to detect any complain earlier and seek appropriate treatment and apply preventive measures. This was in the same line with Amoran et al., (2017) who reported that the majority of young adults in their study were between ages 25-39 years.

Regarding educational level, it was revealed that the majority of parents had secondary school (84, $4 \%)$. While, minority of them had bachelor degree (5.9\%). Secondary level of education will allow parents to understand health information about disease and the preventive measures of crises. This was in the same line with Hamul and Abala, (2012) who reported that majority of the parents had secondary education followed by primary education. Our results are disagreement with Abd El-Gawad, (2017) who reported that 42\% of the mothers were illiterate, $15 \%$ of them had secondary level of education and $10 \%$ of them had university education. Also, Hamul and Abala, (2012) reported that parents who have undergone secondary and tertiary education may find it very easy to understand the health information on the predisposing factors and the preventive measures of crises and in turn may comply with medical advice and put it into their daily practices. 
The findings revealed that number of children in family ranged from one to five, with the average being one with sickle cell disease $(64.7 \%)$. This could be explained by the fact that, couples with sickle cell trait will have each of their pregnancy having $25 \%$ chance of giving birth to a child affected by sickle cell disease. This was in agreement with Hamul and Abala, (2012) who reported that $90 \%$ of the respondents had one child with sickle cell disease while only $10 \%$ had 2 children with the disease. This was in line with Muscari, (2005) who mentioned that majority of the parents (over $80 \%$ ) had only one child with sickle cell disease.

The result showed that the majority of studied sample had no previous training about sickle cell disease $(88.30 \%)$. This demonstrates that parents need for health education to be intensified.This was in line with Gomes et al., (2011) who mentioned that health education on management of sickle cell disease is necessary to ensure better quality in health care. Regarding knowledge of parents about prevention of sickle cell crisis, the current study revealed that all parent didn't identify definition of sickle cell disease on pre intervention compared to post intervention $(94.3 \%)$. So, health education program is very important to prevent crisis. This was agreement with Abd El-Gawad, (2017) who reported that $65 \%$ of the mothers had poor knowledge regarding the definition of SCA pre-test compared to $20.4 \%$ of them post-test.

In another study conducted by Jaffer et al., (2009) who reported that $38 \%$ of parents had little knowledge about SCD, 32\% had moderate knowledge and 30\% had high degree of knowledge. Also, this was in agreement with Yadav, (2017) who reported that after providing education post test scores of knowledge improved significantly (100\%). Similarly, in study conducted by Okoko et al., (2017) who indicated that knowledge of the sickle cell disease in Brazzaville is poor for $66.6 \%$ of parents. This was disagreement with Nakazwe and Siziya, (2017) who reported that respondents had average knowledge about sickle cell and factors that precipitate crises $(53.9 \%)$.

In relation to methods of prevention sickle cell crisis, it was clear that approximately two thirds of parents (64.7\%) had improved knowledge on post intervention. This means that parents would be able to prevent the crises if they are aware about methods of prevention sickle cell crisis. Therefore, there is need to intensify health education about prevention of sickle cell crises. This was in line with Abd El-Gawad, (2017) who reported that the majority of the mothers had poor knowledge pre-test and they are improved post-test. Also, there were statistical significant differences regarding the predisposing factors pre and post-test.

This is in the same line with Hussain et al., (2011) who found that one third of the respondents reported cold and dehydration as predisposing factors while the minority of them reported fever and activities as predisposing factors. A studies conducted by Bethesd, (2002) indicate that parents of children with SCD, had good baseline knowledge related to prevention of dehydration, infections, avoiding exposure to severe cold or heat and getting early medical follow-up for symptoms such as fever, pain assessment and management. This contradiction may be due to the differences in the demographic data, lack of education regarding SCD and lack of mothers' awareness. This was in agreement Okoko et al., (2017) who concluded that parents have a poor knowledge of sickle cell crises.

Regarding Parents reported practices of sickle cell crisis prevention, This findings revealed that more than one third of studied sample were identified methods of prevention sickle cell crisis on pre intervention $(35.3 \%)$ compared to post intervention $(100 \%)$. On post intervention, parents were provided plenty of fluids to reduce frequency of hospitalization (70.6\%) compared to $5.9 \%$ pre intervention. Therefore, there was a highly statistical significance differences between pre and post intervention. So the sickle cell crisis guide improving parents reported practice and reduce the burden of the disease by correct any misconceptions. This was agreement with Okoko et al., (2017) who reported that the findings showed that only $31 \%$ of parents have good practices. As knowledge of vaso-occlusive crises influences the practice $(95 \%)$ it is permissible for the rules of good practice to be taught at any consultation of the sickle cell child. Also, these findings are supported by Fahad et al., (2017) who reported that the majority of the respondents who had adequate knowledge also had positive practices. This was disagreement with Elise et al., (2017) who reported that $88.9 \%$ of the respondents had good practiced.

Regarding social and cultural practices of parents with sickle cell children on prevention of crisis, the study reviewed that majority of parents didn't feel exhausted from providing care on pre and post intervention $(82.4 \%$ and $88.2 \%$ respectively). Percentage of parents who feeling guilt reduced post intervention compared with pre intervention (70.6\%: $44.1 \%$ respectively). Also, it was revealed that $52.9 \%$ of parents didn't use social and cultural practices in prevention of sickle cell crises on pre intervention compared to $79.4 \%$ on post intervention. All these findings show importance to educate parents and children about basic information on sickle cell to reduce wrong social and culture practices. This was agreed with Nakazwe \& Siziya, (2017) who mentioned that $91.2 \%$ of the respondents had a positive attitude towards the disease and they practiced good methods that have the potential to reduce the crises. This was in agreement with Abu Ali \& Abdel Razeq (2017) who mentioned that There is an overarching need of the family for social support and knowledge to maximize the wellbeing of SCD children and their parents. Therefore, giving correct and adequate information on the management of SCD to parents is significant in enhancing their knowledge on prevention of crises

As indicated in the result, parents were suggested booklets for prevention of sickle cell crises on post 
intervention (82.2\%). This clarifies importance of health teaching sessions that improve parents' awareness and practice in management and prevention of sickle cell crisis. This was corresponding with Elise et al., (2017) who reported that $91.2 \%$ of parents had a positive attitude towards the disease and they practiced good methods that have the potential to reduce the crises by health educational programs.

\section{Conclusion:}

Based on findings of the present study, it can be concluded that: there were knowledge deficit between parent about sickle cell disease and prevention sickle cell crisis on pre intervention, while, there were marked improvement in knowledge regarding predisposing factors of sickle cell crisis and methods of treatment sickle cell disease on post implementation of sickle cell crisis prevention guide. Also, there were marked improvements in reported practices post implementation of sickle cell crisis prevention guide.

\section{Recommendations}

Based on the finding of the present study, the researchers recommended:

○ Updating knowledge and practice of parents and newly joined parents about sickle cell disease to improve their knowledge and practice about sickle cell disease and crisis prevention.

○ Continuous observation of parent's performance and correction of poor knowledge, practices and attitude are required.

- Ensure that sickle cell booklets are available to hospitals for parents in order to remind themselves on treatment and prevention of crises.

- Seminars should be focused on the issues about awareness of sickle cell anemia and crisis prevention.

\section{References}

[1] Abbas, H. (2014). Study of serum procalcitonin level in patients with sickle cell disease with or without vaso-occlusive crises. Alexandria University. Faculty of Medicine Departement of Pediatrics. Retrieved from http .wwww/eulc.edu.eg/eulc

[2] Abd El-Gawad, S. (2017). Empowering Mothers to Overcome Sickle Cell Crisis in Their Children through Engagement and AAEducation. American Journal of Nursing Research. 2017, 5(5), 182-190. DOI: 10.12691/ajnr-5-5-4. Volume 5, 2017 - Issue 5. Retrieved from http://www.sciepub.com/journal/ajnr

[3] Abu Ali ,R and Abdel Razeq, N.(2017). The Lived Experience of Parents of Children with Sickle Cell Disease: A Qualitative Study. Retrieved from https:// www. scirp.org/journal / Paper Information.aspx

[4] Adewoyin, A.E. Alagbe, Adedokun, B.O and Idubor, N. (2015). Knowledge, Attitude And Control Practices Of Sickle Cell Disease Among Youth Corps Members In Benin City, Nigeria. Retrieved from https:// www. ncbi.nlm.nih.gov/pmc/articles

[5] Aken'ova, Y. (2013). Distribution of sickle cell disease in Africa. Dokita, University College Hospital, Ibadan, Nigeria. In Ezenwosu, O. Chukwu, B. Ikefuna, J. Hunt, A. Keane, I. Emodi, J \&Ezeanolue, E. (2015). Knowledge and awareness of personal sickle cell genotype among parents of children with sickle cell disease in southeast Nigeria. Retrieved from https://www.ncbi.nlm.nih.gov/pmc/articles

[6] Akinyanju. OO., Otaigbe, AI and Ibidapo, MO. (2005). Outcome of holistic care in Nigerian patients with sickle cell anaemia. Clin Lab Haematol. 2005;27:195-199. http://dx.doi.org/10.1111/j.13652257.2005.00683.x. (Epub 2005/06/09. PubMed PMID:15938726). [PubMed]

[7] Aliyu, Z. Y., Kato, G. J., Taylor IV, J., Babadoko, A., Mamman, A. I., Gordeuk, V. R., \& Gladwin, M. T. (2008). Sickle cell disease and pulmonary hypertension in Africa: a global perspective and review of epidemiology, pathophysiology, and management. American journal of hematology, 83(1), 63-70.]

[8] Amoran, O., Jimoh, A \& Alabi1,A. (2017). Parental Influence on Sickle Cell Crisis among Patients Attending Secondary Facilities in Abeokuta South Local Government Area, Ogun State. British Journal of Medicine \& Medical Research 14(9): 1-10, 2016, Article no.BJMMR.24656 ISSN: 2231-0614, NLM ID: 101570965

[9] Awd, R. (2018). Mother's Knowledge and Practice regarding Care of Their Children with Sickle Cell Anemia. Retrieved from eulc.edu.eg/eulc

[10] Ballas S, Gupta K, Adams-Graves P. (2012). Sickle cell pain: A critical reappraisal. Blood. 2012;120:3647-3656. doi: 10.1182/blood-2012-04-383430. [PubMed] [CrossRef]

[11] Bartolucci, P., and Galactéros, F. (2012). Clinical Management of Adult Sickle-cell Disease. Current Opinion in Hematology, 19(3), 149-155.In NIEKERK, K. (2015). Knowledge and experiences of parents with children affected by Sickle Cell Disease in Cape Town.Faculty of health Sciences.University of Cape Town

[12] Bethesda, MD., (2002). The management of sickle cell disease. 4thed., National Heart, Lung, and Blood Institute, Division of Blood Diseases and Resources, NIH Publication No. 02-2117, 2002.

[13] Diallo D and Tchernia G. (2002). Sickle cell in Africa. Currie Opine Hematol. 2002;9(2):111-6. doi: 
10.1097/00062752-200203000-00005. [PubMed] [CrossRef]

[14] El Safy, H. (2016). Study of the association between the xmn1 $\gamma g$ globin polymorphism (-158c $>$ t) and fetal haemoglobin level in sickle cell disease. Alexandria University. / Faculty of Medicine. -Department of Clinical Pathology. Retrieved from http/www.eulc.edu.eg/eulc

[15] Elise, N., Victor ,M and Seter S.(2017). Knowledge attitude and practices of parents with children suffering from sickle cell disease towards factors that precipitate sickle cell crises,atarthurdavidson children's hospital in Ndola Zambia.

[16] Fahad F. A., Naif F. A., Albandari F. A and Almutairi M. (2017). Assess Mother's Knowledge Regarding Their Children with Sickle Cell Disease., International Journal of Healthcare Sciences. Available at: www.researchpublish.com.

[17] Gomes, L ., Vieira, M., Reis,T., Barbosa, T and Caldeira, A. (2011). Knowledge of family health program practitioners in Brazil about sickle cell disease: a descriptive, cross-sectional study. Published online $2011 \quad$ Aug 19. doi: 10.1186/1471-2296-12-89. Retrieved from https://www.ncbi.nlm.nih.gov/pmc/articles

[18] Hamul, H and Abala, A. (2012). Knowledge and Practices of Parents And Caretakers Towardsprevention Of Sickle Cell Crises In Children With Sickle Cell Disease At The University Teaching Hospital (Lusaka). The University Of Zambia

[19] Haywood, C., Lanzkron, S., Hughes, M. T., Brown, R., Massa, M., Ratanawongsa, N., and Beach, M. C. (2011). A video-intervention to improve clinician attitudes toward patients with sickle cell disease: the results of a randomized experiment. Journal of general internal medicine, 26(5), 518-523.

[20] Howard, J and Oteng-Ntim, E. (2012). The obstetric management of sickle cell disease. Best Practice \& Research Clinical Obstetrics \& Gynaecology, 26(1), 25-36.

[21] Hussain R. Yusuf, MD., Michele A. and Lloyd, P. (2011). Sickle Cell Disease The Need for a Public Health Agenda., American Journal of Preventive Medicine, 2011;41(6S4): S376-S383) Published by Elsevier Inc..

[22] Jenerette, C and Leak, A. (2012). The Role of Oncology Nurses in the Care of Adults With Sickle Cell Disease.Clin J Oncol Nurs. 2012 Dec; 16(6): 633-635.Retieved from https:// www. ncbi. nlm. nih. gov/ pmc/articles

[23] Joshua J, Vichincky E., and DeBaun M.( 2014 ) Overview of the Management and Prognosis of Sickle Cell Disease, Wolters Kluwer, Literature Review Current through: Dec. Available at, http://www.uptodate.com/contents/overview-of-the-management-and-prognosis-of-sickle-cell-disease.

[24] Lal A and Vinchinsky EP. (2011).Sickle cell disease. In: Hoffbrand AV, Catovsky D, Tuddenham EGD, Green AR, editors. Postgraduate Haematology. 6 ed. Vol. 7. Blackwell Publishing Ltd; 2011. pp. 109125.In Adewoyin, A.E. Alagbe, Adedokun, B.O and Idubor, N. (2015). Knowledge, Attitude And Control Practices Of Sickle Cell Disease Among Youth Corps Members In Benin City, Nigeria. Retrieved from https:// www. ncbi.nlm.nih.gov/pmc/articles

[25] Lattimer L, Haywood C, Lanzkron S, Ratanawongsa N, Bediako S and Beach M. (2010). Problematic hospital experiences among adult patients with sickle cell disease. Journal of Health Care for the Poor and Underserved. 2010;21:1114-1123. doi: 10.1353/hpu.2010.0940. [PMC free article] [PubMed][CrossRef]MedlinePlus. Hemoglobin: Normal results. 2014 Retrieved fromhttp://www.nlm.nih.gov/medlineplus/ency/article/003645.htm.

[26] Michael RD, Vichinsky E., Behrman RE, Jenson HB and Stanton BF. (2008). Hemoglobinopathies In Kliegman, Nelson Textbook of pediatrics. 18th ed. New Delhi: Elsevier Publication; p. 2026.

[27] Modell, B. and Darlison, M. (2008). Global Epidemiology of Hemoglobin Disorders and Derived Service Indicator. Bull WHO, 86, 480-487. https://doi.org/10.2471/BLT.06.036673

[28] Muscari ME. (2005). Pediatric nursing. $4^{\text {th }}$ Ed. Lippnocott Williams and Wikings, USA.

[29] Nakazwe,E\&Siziya, V.(2017). Knowledge attitude and practices of parents with children suffering from sickle cell disease towards factors that precipitate sickle cell crises,atarthurdavidson children's hospital in Ndola Zambia. Asian Pac. J. Health Sci., 2017; 4(3):166-170. Received: 13-07-2017 / Revised: 30-07-2017 / Accepted: 15-08-2017.

[30] Oni, L., Dick, M., Walters, J and Rees, D. (2012). A Parent's Guide to Managing Sickle Cell Disease. Brent Sickle Cell \& Thalassaemia Centre

[31] Okoko, A., Eouolo, J. Kambourou E., Moyen, G., Ekouya-Bowassa, B. Diall, A. Mbika-Cardorelle,G and Moyen, G. (2017). Knowledge, Attitudes and Practices of Parents in the Vaso-Occlusive Crises of the Sick Children in Brazzaville. Retrieved from http: //www. scirp. org/journal/ojped

[32] Piel, F.., Patil, A., Howes, R., Nyangiri, O., Gething, P.., Dewi, M. and Hay, S. I.(2013). Global Epidemiology of Sickle Haemoglobin in Neonates : A Contemporary Geostatistical Model-based Map and Population Estimates. The Lancet, 381(9861), 142-151.

[33] Poulami, M., Caughey,M., Robinson,L., Payal,C. Desai, S., Jones, Nouraie, M.,Mark,T. Gladwin, A., Hin 
der, Land Jianwen Cai, K. (2017). Risk Factors For Mortality In Adult Patients With Sickle Cell Disease: A Meta-Analysis Of Studies In North America And Europe. Retrieved from Haematologica April 2017 102: 626 636; Doi:10.3324/haematol.2016.153791

[34] Purnima,Yand Jayant,V. ( 2018). Impact of education on the knowledge and skills of parents of children with sickle cell disease. International Journal of Contemporary PediatricsYadav $\mathrm{P}$ et al. Int J ContempPediatr. 2018 Jan;5(1):209-213.

[35] Rees DC, Williams TN, Gladwin MT. (2010).Sickle-cell disease. Lancet. 376:2018-31. [PubMed: 21131035]

[36] Rees, D. C., Olujohungbe, A. D., Parker, N. E., Stephens, A. D., Telfer, P., and Wright, J. (2003). Guidelines for the management of the acute painful crisis in sickle cell disease. British journal of haematology, 120(5), 744-752.

[37] Sparkenbaugh E and Pawlinski R. (2013). Interplay between coagulation and vascular inflammation in sickle cell disease. British Journal of Haematology. 2013; 162(1):3-14. [PubMed: 23593937]

[38] Tadmouri, G.O., et al. (2009). Consanguinity and Reproductive Health among Arabs. Reproductive Health, 6, 17. https://doi.org/10.1186/1742-4755-6-17. In Abu Ali ,R and Abdel Razeq, N.(2017). The Lived Experience of Parents of Children with Sickle Cell Disease: A Qualitative Study. Retrieved fromhttps:// www. scirp.org /journal/PaperInformation.aspx

[39] Van den, X., Hatzmann, J., Ensink, E., van der Lee, J. H., Peters, M., Fijnvandraat, K., \& Grootenhuis, M. (2008). Quality of life of female caregivers of children with sickle cell disease: a survey. haematologica, 93(4), 588-593

[40] Valente S, Alexander J, Blount M, Fair J, Goldsmith C and Williams L. (2010). Sickle cell disease in emergency department: Education for emergency nurses. JOCEPS: The Journal of Chi Eta Phi Sorority. 2010;54:11-14.

[41] World Health Organization. (2016). Fifty-Ninth World Health Assemblies. Sickle Cell Disease. A59/9, 24 April 2016. In Okoko, A., Eouolo, J. Kambourou E., Moyen, G., Ekouya-Bowassa, B. Diall,A. MbikaCardorelle,G and Moyen, G. (2017). Knowledge, Attitudes and Practices of Parents in the Vaso-Occlusive Crises of the Sick Children in Brazzaville. Retrieved fromhttp://www.scirp.org/journal/ojped

[42] Xandra W., Hatzmann, J., Elske, E., Johanna, H., Peters, M and Martha, G.(2008). Quality of Life of Female Caregivers of Children with Sickle Cell Disease: a Survey, Haematological; 93(4):588-593.

[43] Yadav, P and Vagha, J. (2017). Impact of education on the knowledge and skills of parents of children with sickle cell disease. International Journal of Contemporary Pediatrics. DOI: http://dx.doi.org/10.18203/2349-3291.ijcp20175588. Retrieved from https://www .ijpediatrics. com/ index. Php /ijcp/article

[44] Yawn, BP., Buchanan GR and Annan, AN. (2014). Management of sickle cell disease: summary of the 2014 evidence-based report by expert panel members. JAMA 312: 1033-1048. 